\title{
17. PALEOGENE OXYGEN ISOTOPE RECORD FOR DEEP SEA DRILLING SITES 511 AND 512, SUBANTARCTIC SOUTH ATLANTIC OCEAN: PALEOTEMPERATURES, PALEOCEANOGRAPHIC CHANGES, AND THE EOCENE/OLIGOCENE BOUNDARY EVENT ${ }^{1}$
}

\author{
Jay P. Muza, Department of Geology, Florida State University, Tallahassee, Florida \\ Douglas F. Williams, Department of Geology, University of South Carolina, Columbia, South Carolina \\ and \\ Sherwood W. Wise, Jr., Department of Geology, Florida State University, Tallahassee, Florida
}

\begin{abstract}
An Eocene-Oligocene oxygen and carbon isotope history based on planktonic and benthic foraminifers from Deep Sea Drilling Project Leg 71 cores has been constructed for the Maurice Ewing Bank of the eastern Falkland Plateau, Southwest Atlantic Ocean. Specifically, the cores cover portions of the middle Eocene, upper Eocene, and lower Oligocene. Surface water isotopic temperatures postulated for the middle Eocene at Site 512 fluctuated within about four degrees but generally averaged about $9^{\circ} \mathrm{C}$. Bottom isotopic temperatures at Site 512 (water depth, $1846 \mathrm{~m}$ ) were generally a degree lower than surface water temperatures.

Surface water isotopic temperatures at Site 511 initially averaged about $11^{\circ} \mathrm{C}$ during the late Eocene, but dropped to an average of $7^{\circ} \mathrm{C}$ in the early Oligocene. Bottom isotopic temperatures at Site 511 (water depth, $2589 \mathrm{~m}$ ) generally record temperatures between $12.5^{\circ} \mathrm{C}$ and $8^{\circ} \mathrm{C}$, similar to the range in the surface water isotopic temperatures. During the early Oligocene, bottom isotopic temperatures dropped sharply and averaged about $2^{\circ} \mathrm{C}$ (very close to present-day values). Surface water temperature values also decreased to an average of about $7^{\circ} \mathrm{C}$, therefore leading to a significant divergence between surface and bottom water isotopic temperatures during the early Oligocene. Comparisons among Southern Ocean DSDP Sites 511, 512, and 277, and between these and other DSDP sites from central and northern latitudes (Sites 44, 167, 171, 292, 357, 398, 119, and 401) show that much of the Eocene was characterized by relatively warm temperatures until sometime in either the middle Eocene, late Eocene, or early Oligocene. At each site, conspicuous ${ }^{18} \mathrm{O}$ enrichments occur in both the benthic and planktonic foraminifers over a relatively short period of time. Although a general trend toward a climatic deterioration is evident, the density of data points among the various studies is still too sparse to determine either synchrony or time-transgression between the major isotopic events.

A close correlation could be made between the Site 511 oxygen isotope temperature curve and paleoclimatic trends derived independently from radiolarian studies. The sharp temperature drop and the divergence between bottom and surface water temperatures during the early Oligocene apparently reflect a major expansion of the antarctic water mass. The migration of the boundary between the subantarctic and antarctic water masses over the site at this time would account in part for the sharp temperature changes. Sharp changes of this nature would not necessarily be noted in other geographic areas, particularly those to the north which have different oceanographic regimes.
\end{abstract}

\section{INTRODUCTION}

Because the carbonate compensation depth rises steeply as one approaches the poles (Berger and Winterer, 1974; Ramsay, 1977), carbonate sections suitable for stable isotope studies are difficult to obtain in the high latitudes, even with the capabilities of deep sea drilling. This difficulty poses an acute problem for the paleoclimatologist because the earliest indications of Tertiary climate deterioration should be recorded in sediments of high-latitude oceans.

In the Southern Ocean, the most successful attempts to obtain suitable Tertiary sections have been carried out in the Pacific sector, where DSDP Leg 29 cored long Tertiary sequences on the Campbell Plateau and Macquarie Ridge (Kennett, Houtz, et al., 1975). Stable isotope studies of these materials by Shackleton and Kennett (1975) not only documented the general deterioration of Cenozoic climates, but showed that this deterio-

\footnotetext{
${ }^{1}$ Ludwig, w. J., Krasheninnikov, v. A., et al., Init. Repts. DSDP, 71: Washington (U.S. Govt. Printing Office).
}

ration was punctuated by a number of sharp steps which appeared to reflect global climatic events. One of the most profound of these events occurred during the early Oligocene, when a sudden and pronounced drop in both surface and bottom water temperatures led Shackleton and Kennett (1975) to suggest that the buildup of glacial ice on the Antarctic continent had reached a critical threshold, sufficient to cause the initiation of Antarctic bottom water circulation. This in turn changed the general character of oceanic circulation throughout the world's oceans.

Some disagreement has been expressed in the literature as to the exact timing and significance of this event (Mercer, 1978, Corliss, 1981; Miller and Curry, in press; Keigwin, 1980), and no additional comparable sections were available from other high-latitude regions of the Southern Hemisphere to corroborate the original findings from Leg 29. For this reason, the acquisition of a carbonate-bearing sequence across the Eocene/Oligocene boundary on the Falkland Plateau in the Atlantic sector of the Southern Ocean during DSDP Leg 71 is of special interest. The purpose of this study is to relate the Paleogene oxygen isotope record from DSDP Sites 
511 and 512 to those previously obtained by Shackleton and Kennett (1975) and others. Paleoclimatic trends obtained from these isotope data are also related to trends obtained independently by microfaunal analyses (Weaver, this volume; Basov and Krasheninnikov, this volume; Krasheninnikov and Basov, this volume).

\section{BACKGROUND}

Leg 71 of the Deep Sea Drilling project was the second cruise of the Glomar Challenger to the Falkland Plateau and the Maurice Ewing Bank in the Southwest Atlantic sector of the Southern Ocean. The Maurice Ewing Bank is a domelike feature which occupies the eastern extremity of the Falkland Plateau (Fig. 1). Drilling by Glomar Challenger during DSDP Legs 36 and 71 has shown that the bank is mantled by a thick sequence of carbonate and siliceous pelagic sediments of Cretaceous and Tertiary age.

The two sites drilled on the Maurice Ewing Bank (Fig. 1) during Leg 71, Site 511 on its western margin $\left(51^{\circ} 00.28^{\prime} \mathrm{S}, 46^{\circ} 58.30^{\prime} \mathrm{W}\right)$, and Site 512 on its eastern margin $\left(49^{\circ} 52.194^{\prime} \mathrm{S}, 40^{\circ} 50.713^{\prime} \mathrm{W}\right)$, were chosen to better define major Tertiary erosional events and CCD fluctuations as well as to establish the biostratigraphy of high-latitude calcareous microfossils and their correlation with oxygen isotope and paleomagnetic data.

Sites 511 and 512 together provide an almost continuous sequence of carbonate sediments through the Eocene/Oligocene boundary. The Paleogene at Site 511 is represented by approximately 154 meters of lower Oligocene nannofossil ooze and 28 meters of upper Eocene nannofossil ooze (Fig. 2). The primary limitations of the sequence at Site 511 are poor core recovery and intervals barren of calcareous microfossils in critical cores. The latest Eocene foraminiferal Zone P17 is not present in the cores. The lowermost Oligocene core (Core 511-16) is barren of calcareous microfossils, and samples from Cores 13 and 14 were not available for this study because of the poor core recovery. Cores 12 , 15,17 , and 18 are abbreviated. Unfortunately, the site was not hydraulically piston cored, as Site 512 was.

At Site 512, the Paleogene is represented by approximately 70 meters of middle Eocene siliceous nannofossil ooze. Sedimentation rates average $44 \mathrm{~m} / \mathrm{m}$.y. at Site 511 for the late Eocene and early Oligocene, and 70 $\mathrm{m} / \mathrm{m} . \mathrm{y}$. at Site 512 for the middle Eocene. In most cases, these sediments are sufficiently rich to provide adequate amounts of benthic and planktonic foraminifers for stable isotope analyses.

Scanning electron micrographs show that the planktonic and benthic foraminifers are extremely well preserved in Site 511 and 512 cores, with the possible exception of Sections 512-19-1 and 512-19-2. In these cores some coccoliths show signs of overgrowths (Wise, this volume).

It should be emphasized at the outset that the Leg 71 sites lie at intermediate $(2000-2500 \mathrm{~m})$ rather than deep abyssal (4000-5000 m) depths. Today, these sites lie within the path of circumpolar deep water flow, not Antarctic Bottom Water (see Wise, 1981, fig. 2). Any references in the present study to bottom temperatures or isotopic values at these sites therefore refer to those existing at intermediate depths rather than true abyssal depths.

\section{Previous Studies}

Studies involving the variation in the oxygen isotopic composition of benthic and planktonic foraminifers across the Eocene/Oligocene boundary are summarized in Table 1. In general, these studies noted a 1.0 to $2.0 \%$ 。 enrichment in ${ }^{18} \mathrm{O}$ occurring from the middle Eocene through early Oligocene in both planktonic and benthic foraminifers. These studies also showed that approximately $1.0 \%$ of this change occurs in the vicinity of the Eocene/Oligocene boundary. However, there are some exceptions to these general trends. At Site 292 in the Philippine Sea, ${ }^{18} \mathrm{O}$ enrichment occurs only in the benthic foraminifers (Keigwin, 1980). At Site 357 in the South Atlantic, the ${ }^{18} \mathrm{O}$ enrichment in both benthic and planktonic foraminifers occurs in the middle and late Eocene only (Boersma and Shackleton, 1977). Lastly, at Site 398 in the North Atlantic, there is a $2.0 \%{ }_{0} \delta^{18} \mathrm{O}$ increase in both planktonic and benthic foraminifers which occurs at the middle/late Eocene boundary (Vergnaud Grazzini et al., 1979).

Other studies trace changes in oxygen isotope ratios of nannofossils through the Eocene and early Oligocene. Douglas and Savin (1975) noted a $1.3 \% 0 \delta^{18} \mathrm{O}$ enrichment between planktonic foraminiferal Zones P10 and P18 at Site 305 on the Shatsky Rise, and a $0.9 \%$ enrichment at Site 167 in the central equatorial Pacific between Zones P18 and.P19/20 (early Oligocene). In addition, Devereux (1967) noted a substantial ${ }^{18} \mathrm{O}$ enrichment at the Eocene/Oligocene boundary in macro- and microfossils from a land section in New Zealand.

\section{METHODS}

One $10 \mathrm{~cm}^{3}$ plug of sediment was taken from each section, where practical, of the Paleogene sequence cored at Sites 511 and 512. To concentrate and clean the foraminifers in these sediments, the sediment was washed through a $63 \mu \mathrm{m}$ sieve after soaking in a solution of distilled water and Calgon. The fraction $>63 \mu \mathrm{m}$ was ultrasonically cleaned and dried. Both benthic and planktonic foraminifers were picked from each sample interval for isotopic analyses.

The planktonic foraminifers analyzed from Site 511 were a mixed assemblage of Globigerina angiporoides and $G$. aff. linaperta in varying ratios for each sample. From Site $512, G$. angiporoides and $G$. linaperta were used. A typical sample for isotopic analysis contained approximately $30-35$ specimens. The benthic foraminifers from Site 511 were a mixed assemblage of many different genera (see Appendix). The benthic foraminifers analyzed from Site 512 were Cibicidoides parki. A typical benthic sample for analysis contained approximately $10-15$ specimens.

Each foraminiferal sample was loaded into a stainless steel boat, crushed, roasted in a vacuum for one hour at $380^{\circ} \mathrm{C}$, and then reacted in vacuo with purified orthophosphoric acid at $50^{\circ} \mathrm{C}$ until the reaction was complete. The $\mathrm{H}_{2} \mathrm{O}$ and $\mathrm{CO}_{2}$ produced by this reaction were separated by a series of distillation steps. The resultant $\mathrm{CO}_{2}$ gas was analyzed with a VG-Micromass 602D isotope ratio mass spectrometer.

The results are reported in terms of the isotopic difference between the $\mathrm{CO}_{2}$ sample and that of the PDB standard (Epstein et al., 1953). Calibration of the laboratory reference gas to PDB was made through the use of ancillary carbonate powders NBS-20, TKL-1, B-1, and Paris-Sirap.

Analytical precision based on the routine analysis of 16 samples of NBS-20 is $\pm 0.07 \%$ for $\delta^{18} \mathrm{O}$ and $\pm 0.09 \%$ for $\delta^{13} \mathrm{C}(1 \sigma)$. Instrumental errors for individual determinations of $\delta^{18} \mathrm{O}$ and $\delta^{13} \mathrm{C}$ generally range from $< \pm 0.01$ to \pm 0.07 . 


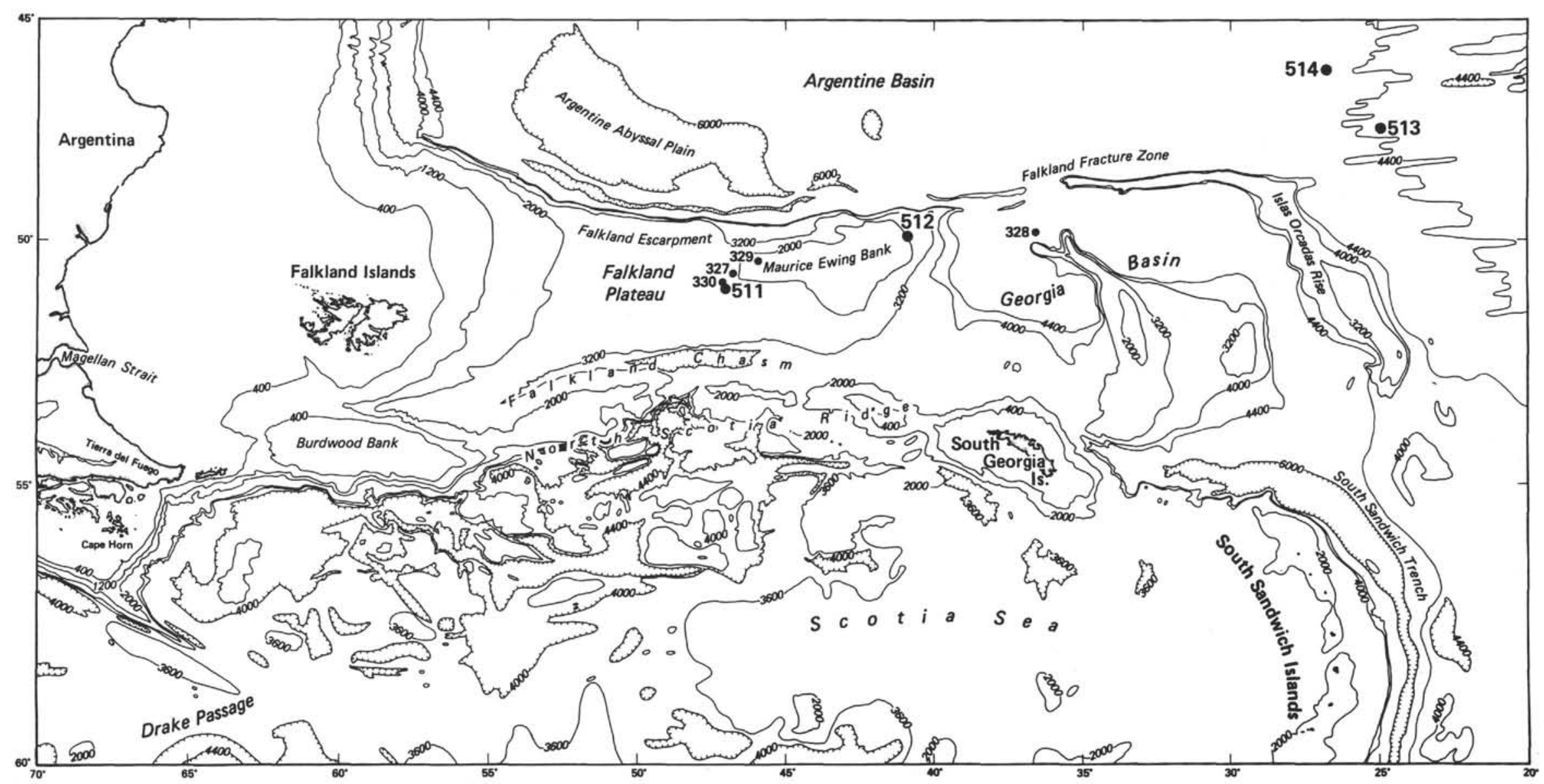

Figure 1. Location of DSDP Leg 71 Sites 511 and 512. 

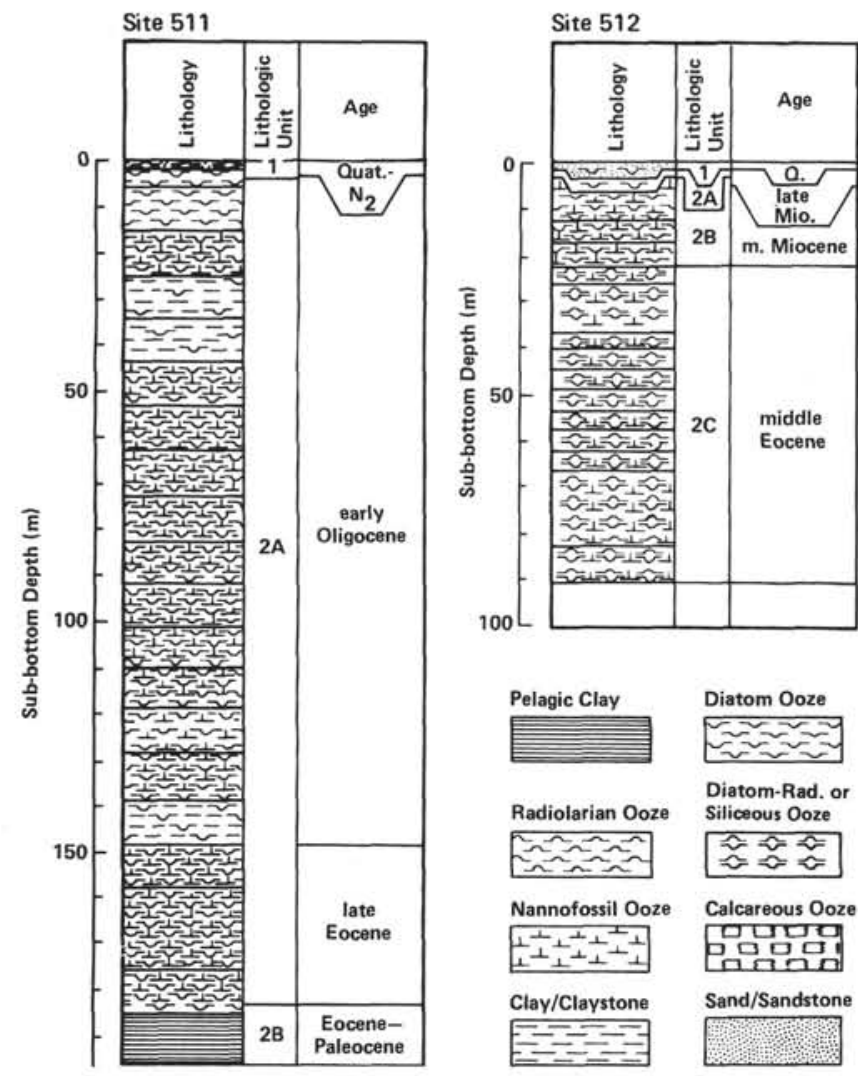

Thus the error (estimated $1 \sigma$ from Dixon and Massey, 1957, p. 407) is $<0.10$ for $\delta^{18} \mathrm{O}$ and $<0.12$ for $\delta^{13} \mathrm{C}$.

The oxygen isotope data were submitted to the statistical technique called "runs analysis." Because this procedure has not been previously applied in this type of study, the technique is briefly explained here. Runs analysis is a nonparametric statistical method which evaluates the randomness of linearly distributed data and therefore is well suited to any study concerned with variations within a downcore sequence. A run is a set of consecutive data points which are either all above or all below the median value for all data. A nonrandom distribution of the data is indicated by a critically small number of runs (representing long-term variation) or by a critically high number of runs (representing cyclic variation). Randomly distributed downcore data would be indicated by a number of runs which are intermediate to the number of runs representing cyclic or long-term variation.

\section{RESULTS}

\section{Site 512}

The results of the oxygen and carbon isotopic analyses of foraminifers from the middle Eocene section of Site 512 are shown in Table 2 and Figure 3 as per mil deviations from the PDB standard. Given the possible sources of error, it appears that the benthic and planktonic foraminiferal oxygen isotope curves show no significant trends through the middle Eocene at this site. The benthic curve shows consistent enrichment in ${ }^{18} \mathrm{O}$ relative to the planktonic curve. Planktonic $\delta^{18} \mathrm{O}$ values lie between -0.16 and $0.72 \%$. Benthic $\delta^{18} \mathrm{O}$ values range from -0.22 to $0.84 \%$.

The carbon isotope curves for both planktonic and

Figure 2. Sites 511 and 512 Cenozoic stratigraphic sections.

For 4 different samples, duplicate aliquots of foraminifers were picked and analyzed separately. Results are:

\begin{tabular}{lcc}
\hline \multicolumn{1}{c}{ Section } & $\delta^{18} \mathrm{O}$ & ${ }^{13} \mathrm{C}$ \\
\hline 512-7-3, benthic & -0.61 & 0.01 \\
& -0.68 & 0.02 \\
$512-11-3$, planktonic & -0.90 & 0.61 \\
& -1.01 & 0.69 \\
$512-18-2$, benthic & -0.50 & 0.53 \\
& -0.50 & 0.61 \\
512-18-3, benthic & -0.49 & 0.45 \\
& -0.54 & 0.59 \\
\hline
\end{tabular}
benthic foraminifers from Site 512 appear to be an approximate mirror image. Where planktonic foraminifers show a marked ${ }^{13} \mathrm{C}$ enrichment, the benthics are depleted in ${ }^{13} \mathrm{C}$. $\delta^{13} \mathrm{C}$ values range from approximately $0.48 \%$ to $1.42 \%$ for planktonic foraminifers, and from $-0.30 \%$ to $0.66 \%$ for benthic foraminifers.

\section{Site 511}

The results of the oxygen and carbon isotopic analyses of foraminifers from Site 511 are illustrated in Table 3 and Figure 4. The oxygen isotope curve for the Paleogene section of Site 511 appears to be divided into three distinct units (Fig. 4). From Section 511-20-2 to 511-15-1, $\delta^{18} \mathrm{O}$ values for both planktonic and benthic foramini-

Table 1. Studies of variation in the oxygen isotopic composition of benthic and planktonic foraminifers across the Eocene/Oligocene boundary.

\begin{tabular}{|c|c|c|c|c|c|}
\hline Sites & Location & Foram & $\begin{array}{l}\text { Biozone in } \\
\text { Which Change } \\
\text { Takes Place }\end{array}$ & $\begin{array}{c}\text { Approximate } \\
\delta^{18} \mathrm{O} \\
\text { Enrichment }\end{array}$ & 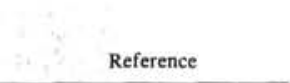 \\
\hline \multirow[t]{2}{*}{167} & Central Equatorial & B & P14-P17 & 1.0 & Douglas and Savin, 1973 \\
\hline & Pacific & $\mathbf{P}$ & P14-P17 & 1.0 & \\
\hline \multirow[t]{2}{*}{44,171} & Central North & B & P16-P18 & 1.0 & Douglas and Savin, 1971, \\
\hline & Pacific & $\mathbf{P}$ & P13-P18 & 1.0 & 1973 \\
\hline \multirow[t]{4}{*}{277} & Campbell Plateau & B & early to late Eocene & 2.0 & Shackleton and Kennett, 1975 \\
\hline & & $\mathbf{P}$ & early to late Eocene & 2.0 & \\
\hline & & B & earliest Oligocene & 1.0 & \\
\hline & & $\mathbf{P}$ & earliest Oligocene & 0.8 & \\
\hline \multirow[t]{2}{*}{277} & Campbell Plateau & B & Eocene/Oligocene boundary & 1.0 & Keigwin, 1980 \\
\hline & & $\mathbf{P}$ & Eocene/Oligocene boundary & 1.0 & \\
\hline \multirow[t]{2}{*}{292} & $\begin{array}{l}\text { West Philippine } \\
\text { Sea }\end{array}$ & B & $\begin{array}{l}\text { From Eocene/Oligocene } \\
\text { boundary for a duration }\end{array}$ & 1.0 & Keigwin, 1980 \\
\hline & & $P$ & of 0.9 m.y. & 0.3 & \\
\hline \multirow[t]{2}{*}{357} & Rio Grande Rise, & B & P14-P17 & 1.0 & Boersma and Shackleton, 1977 \\
\hline & South Atlantic & P & P13-P14 & 1.0 & \\
\hline \multirow[t]{2}{*}{398} & Off Portugal, & B & P15-P16 & 2.5 & Vergnaud Grazzini et al., 1978 \\
\hline & Northeast Atlantic & $\mathbf{P}$ & P13/14-P16 & 2.0 & Vergnaud Grazzini, 1979 \\
\hline 119,401 & Bay of Biscay & B & P15/16-NP21 & 1.4 & Miller and Curry, in press \\
\hline
\end{tabular}

Note: B, Benthic foraminifers; P, Planktonic foraminifers; biostratigraphic zones after Blow; table after Keigwin (1980). 
Table 2. Oxygen and carbon isotope data from middle Eocene foraminifers, Hole 512, expressed as per mil deviations from PDB.

\begin{tabular}{|c|c|c|c|c|}
\hline \multirow{2}{*}{$\begin{array}{l}\text { Core/Section } \\
\text { (interval in } \mathrm{cm} \text { ) }\end{array}$} & \multicolumn{2}{|c|}{$\delta^{18} \mathrm{O}$ PDB } & \multicolumn{2}{|c|}{$\delta^{13} \mathrm{CPDB}$} \\
\hline & Benthic & Planktonic & Benthic & Planktonic \\
\hline $6-1,86-88$ & 0.70 & 0.50 & 0.33 & 0.88 \\
\hline $6-2,13-15$ & 0.45 & 0.17 & -0.30 & 1.17 \\
\hline $7-1,101-103$ & 0.54 & 0.41 & 0.25 & 0.55 \\
\hline $7-2,101-103$ & 0.72 & - & 0.12 & - \\
\hline $7-3,66-68$ & 0.38 & 0.39 & 0.02 & 0.71 \\
\hline $8-1,73-75$ & 0.84 & 0.48 & 0.26 & 0.87 \\
\hline $9-2,98-100$ & 0.71 & 0.15 & 0.26 & 0.92 \\
\hline $10-2,28-30$ & - & 0.26 & - & 0.79 \\
\hline $10-3,23-25$ & - & 0.39 & - & 0.69 \\
\hline $11-1,82-84$ & 0.42 & 0.20 & 0.16 & 0.87 \\
\hline $11-2,64-66$ & 0.62 & - & 0.41 & - \\
\hline $11-3,56-58$ & 0.54 & -0.02 & 0.34 & 0.67 \\
\hline $12-1,62-64$ & 0.07 & 0.39 & -0.06 & 0.95 \\
\hline $12-2,62-64$ & 0.71 & 0.43 & 0.14 & 0.98 \\
\hline $12-3,62-64$ & 0.38 & 0.20 & 0.28 & 1.19 \\
\hline $13-1,46-48$ & 0.55 & 0.52 & 0.30 & - \\
\hline $13-2,49-51$ & 0.62 & 0.02 & 0.15 & 0.57 \\
\hline $13-3,49-51$ & 0.29 & 0.16 & 0.28 & 1.02 \\
\hline $14-1,77-79$ & - & 0.72 & - & 1.42 \\
\hline $14-2,54-56$ & - & 0.60 & - & 0.77 \\
\hline $14-3,27-29$ & 0.57 & 0.06 & 0.62 & 0.68 \\
\hline $15-1,74-76$ & 0.35 & 0.30 & 0.46 & 1.04 \\
\hline $15-2,28-29$ & 0.48 & - & 0.65 & - \\
\hline $15-3,19-21$ & 0.62 & 0.03 & 0.52 & 0.48 \\
\hline $16-1,36-38$ & 0.31 & 0.20 & 0.47 & 0.65 \\
\hline $16-2,23-25$ & 0.69 & 0.51 & 0.61 & 0.77 \\
\hline $17-1,38-40$ & 0.48 & 0.43 & 0.53 & 0.87 \\
\hline $17-2,31-33$ & 0.57 & 0.35 & 0.46 & 0.98 \\
\hline $17-3,28-30$ & 0.63 & - & 0.48 & - \\
\hline $18-1,46-48$ & - & 0.42 & - & 0.87 \\
\hline $18-2,28-30$ & 0.49 & - & 0.66 & - \\
\hline $18-3,11-13$ & 0.45 & 0.62 & 0.65 & 0.90 \\
\hline $19-1,11-13$ & -0.22 & -0.16 & -0.02 & 1.08 \\
\hline $19-2,42-44$ & 0.37 & 0.23 & 0.54 & 0.99 \\
\hline
\end{tabular}

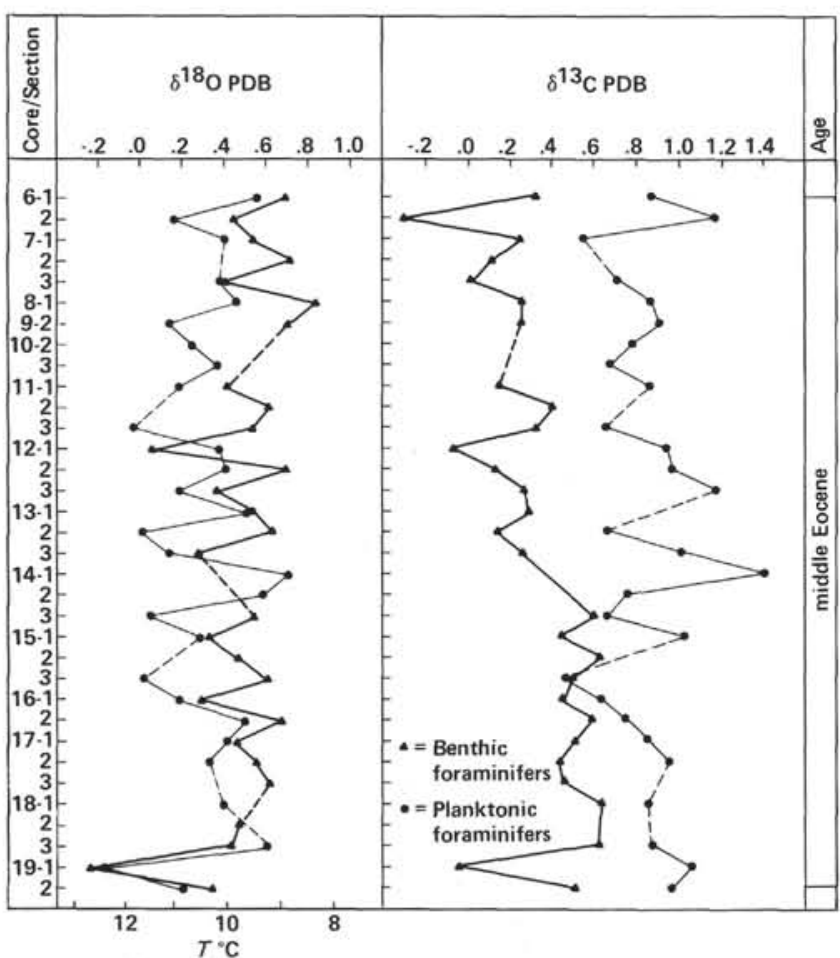

Figure 3. Site 512 oxygen and carbon isotope data from planktonic and benthic foraminifers. Stratigraphic divisions are not based on thickness or absolute age. Samples are plotted arbitrarily at constant divisions. $\delta^{18} \mathrm{O}$ and $\delta^{13} \mathrm{C}$ are reported as deviations per mil from PDB. Paleotemperatures are calculated using Shackleton's (1974) paleotemperature equation and a $\delta_{w}$ of $-1.2 \%$. (Dashed sections indicate gaps in isotopic record because of missing data.)
Table 3. Oxygen and carbon isotope data from late Eocene and early Oligocene foraminifers, Site 511, expressed as per mil deviations from PDB.

\begin{tabular}{|c|c|c|c|c|}
\hline \multirow{2}{*}{$\begin{array}{l}\text { Core/Section } \\
\text { (interval in cm) }\end{array}$} & \multicolumn{2}{|c|}{$\delta^{18} \mathrm{O}$ PDB } & \multicolumn{2}{|c|}{${ }^{813} \mathrm{C}$ PDB } \\
\hline & Benthic & Planktonic & Benthic & Planktonic \\
\hline $3-1,106-108$ & - & 0.24 & - & 0.56 \\
\hline $3-2,106-108$ & 1.35 & 0.51 & -1.88 & 0.74 \\
\hline $3-3,106-108$ & 2.04 & 1.26 & -1.15 & 1.10 \\
\hline $4-1,45-47$ & 2.21 & 1.39 & -1.21 & 0.61 \\
\hline $4-2,45-47$ & 1.75 & 1.00 & -1.40 & 0.56 \\
\hline $4-3,45-47$ & 2.02 & 1.20 & -1.28 & 0.46 \\
\hline $5-1,78-80$ & 2.26 & - & -1.55 & - \\
\hline $5-2,78-80$ & 2.54 & 1.34 & -2.12 & 0.71 \\
\hline $5-3,78-80$ & 2.61 & 1.26 & -1.68 & 0.81 \\
\hline $5-4,78-80$ & 2.43 & 1.17 & -1.72 & 0.80 \\
\hline $6-1,25-27$ & - & 0.98 & - & -0.16 \\
\hline $6-2,25-27$ & 1.96 & 0.77 & -1.88 & -0.01 \\
\hline $6-3,25-27$ & 1.68 & 1.06 & -2.86 & 0.18 \\
\hline $6-4,25-27$ & 2.68 & 1.00 & -1.48 & 0.34 \\
\hline $9-1,127-129$ & 2.51 & 1.40 & -0.77 & 0.86 \\
\hline $9-2,96-98$ & 2.42 & - & -1.28 & - \\
\hline $9-3,96-98$ & 2.62 & 1.36 & -1.40 & 0.48 \\
\hline $9-4,96-98$ & 2.22 & 1.72 & -2.01 & 1.29 \\
\hline $9-5,96-98$ & 3.01 & 1.06 & -1.43 & -0.04 \\
\hline $9-7,46-48$ & 2.11 & 1.22 & -1.68 & 0.56 \\
\hline $11-1,44-46$ & - & 1.24 & - & -0.54 \\
\hline $12-1,70-72$ & 2.42 & 1.32 & -1.16 & 1.00 \\
\hline $12-2,70-72$ & 2.08 & 0.21 & -1.63 & 0.32 \\
\hline $15-1,60-62$ & 0.30 & - & -2.08 & - \\
\hline $17-1,87-89$ & 1.03 & 0.89 & -1.76 & 0.71 \\
\hline $17-2,87-89$ & - & 0.78 & - & 0.70 \\
\hline $17-3,10-12$ & -0.13 & - & -2.82 & - \\
\hline $18-1,24-26$ & -0.15 & -0.16 & -2.80 & 0.35 \\
\hline $20-1,26-28$ & - & 0.22 & - & 0.50 \\
\hline $20-2,26-28$ & 1.27 & 0.25 & -2.74 & 0.62 \\
\hline
\end{tabular}

fers range between -0.16 and $1.27 \%$. There is little deviation in $\delta^{18} \mathrm{O}$ values between planktonic and benthic foraminifers, where the difference between the planktonic and benthic $\delta^{18} \mathrm{O}$ is $<1.00 \%$.

From Sections $511-12-2$ to $511-3-3, \delta^{18} \mathrm{O}$ values for planktonic foraminifers range from 0.21 to $1.72 \%$ (Fig. 4). Between Sections 511-12-2 and 511-12-1, there is a $1.11 \%{ }^{18} \mathrm{O}$ enrichment in the planktonic foraminifers. Benthic foraminifer $\delta^{18} \mathrm{O}$ values between Sections 51112-2 and 511-3-3 range from 1.68 to $3.01 \%$. Between Sections 511-15-1 and 511-12-2, there is a substantial ${ }^{18} \mathrm{O}$ enrichment of $1.78 \%$ in the benthic foraminifers. Between Sections 511-3-3 and 511-3-1, the planktonic $\delta^{18} \mathrm{O}$ curve indicates an ${ }^{18} \mathrm{O}$ depletion of $1.02 \%$. The benthic data indicate a $\delta^{18} \mathrm{O}$ depletion of $0.68 \%$ o between Sections 511-3-3 and 511-3-2.

From Sections 511-12-2 to 511-3-1, and in Section 511-20-2, the $\delta^{18} \mathrm{O}$ values of planktonic and benthic foraminifers from the same sample are significantly different (Fig. 4). The difference in the $\delta^{18} \mathrm{O}$ values between Sections 511-20-2 and 511-15-1 may not be significant. The planktonic and benthic foraminifer $\delta^{18} \mathrm{O}$ curves between Sections 511-20-2 and 511-3-1 are strikingly parallel.

The most noticeable characteristic of the carbon isotope data from Site 511 is the large difference in the planktonic and benthic $\delta^{13} \mathrm{C}$ values from the same sample (Fig. 4). Benthic $\delta^{13} \mathrm{C}$ values range from -2.86 to $-0.77 \%$. Planktonic $\delta^{13} \mathrm{C}$ values range between -0.54 and $1.29 \%$. The greatest difference between planktonic and benthic foraminifer $\delta^{13} \mathrm{C}$ values occurs in Section $511-18-1$ at $3.15 \%$, the least in Section $511-9-5$ at $1.39 \%$. The relatively large differences in the $\delta^{13} \mathrm{C}$ be- 


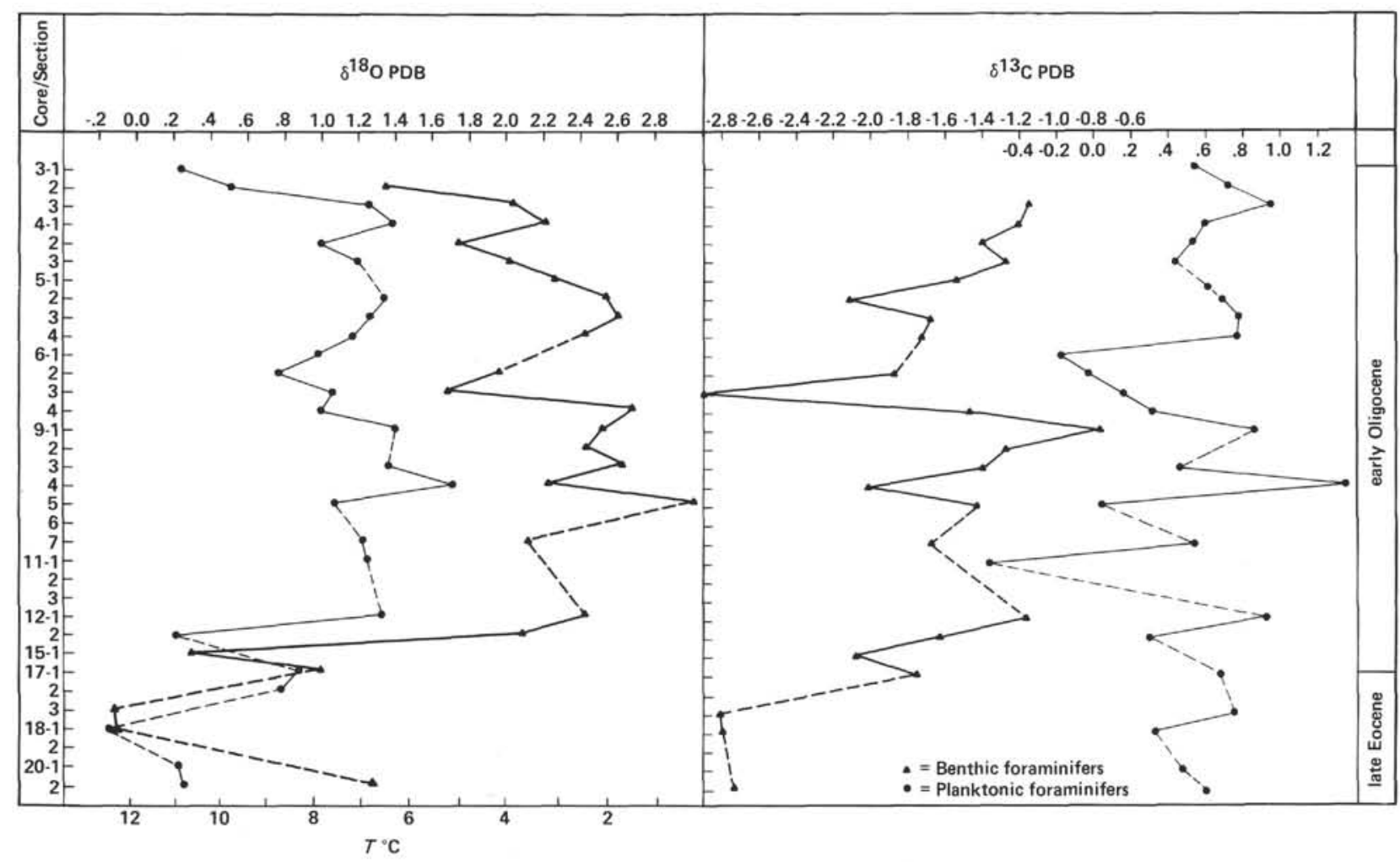

Figure 4. DSDP Leg 71 Site 511 oxygen and carbon isotope data from planktonic and benthic foraminifers. Stratigraphic divisions are not based on thickness or absolute age. Samples are plotted arbitrarily at constant divisions. $\delta^{18} \mathrm{O}$ and $\delta^{13} \mathrm{C}$ are reported as deviations per mil from PDB. Paleotemperatures are calculated using Shackleton's (1974) paleotemperature equation and a $\delta_{w}$ of $-1.2 \%$. (Dashed sections indicate gaps in isotopic record because of missing data.)

tween samples on the same curve are also apparent and are greater than $2 \%$.

Runs analysis was performed on the planktonic and benthic data from the composite Paleogene stratigraphic interval at Sites 511 and 512. For the planktonic data through the composite core sections, runs analysis indicates long-range variation which corresponds to the abrupt change in $\delta^{18} \mathrm{O}$ between Sections 511-15-1 and 51112-2. A similar upsection increase in $\delta^{18} \mathrm{O}$ is indicated by the benthic data from the two sites. The statistical confidence of both analyses is $>99.5 \%$. Thus, the composite section can be resolved into an interval of low $\delta^{18} \mathrm{O}$ values stratigraphically beneath an interval with high $\delta^{18} \mathrm{O}$ values. Runs analyses of the data for the resolved individual intervals produced contrary results for planktonic and benthic data. Benthic data from the lower interval appear to be cyclic $(97.5 \%$ confidence) whereas the benthic data from the higher interval exhibit significantly few runs at a confidence of $97.5 \%$. In contrast, the planktonic data are randomly distributed within each of the intervals.

\section{ISOTOPIC PALEOTEMPERATURE ESTIMATES}

It is possible to estimate paleotemperatures from oxygen isotope ratios derived from carbonate tests of fossil foraminifers (Emiliani, 1954, 1955; Douglas and Savin, 1971, 1973, 1975; Shackleton and Kennett, 1975; and others), if the following criteria can be fulfilled:

1) The ${ }^{18} \mathrm{O} /{ }^{16} \mathrm{O}$ ratio of the water in which the test was precipitated must be known or inferred.
2) Precipitation of the carbonate test must be deposited either in isotopic equilibrium with seawater or out of equilibrium by a constant amount which can be determined.

3) There has been no isotopic change in the fossil carbonate from diagenesis or weathering.

Once these conditions have been satisfied, it is possible to calculate the temperature at which the organism secreted its test using the paleotemperature equation

$$
T^{\circ} \mathrm{C}=16.9-4.38\left(\delta_{c}-\delta_{w}\right)+0.10\left(\delta_{c}-\delta_{w}\right)^{2},
$$

where $\delta_{c}=\delta^{18} \mathrm{O}$ calcite relative to $\mathrm{PDB}, \delta_{w}=\delta^{18} \mathrm{O}$ water relative to $\mathrm{PDB}$, and

$$
\delta^{18} \mathrm{O}=\left(\frac{{ }^{18} \mathrm{O} /{ }^{16} \mathrm{O} \text { sample }-{ }^{18} \mathrm{O} /{ }^{16} \mathrm{O} \text { standard }}{{ }^{18} \mathrm{O} /{ }^{16} \mathrm{O} \text { standard }}\right) \times 1000
$$

This equation (Shackleton, 1974) represents an expression of isotopic equilibrium between water and calcite (O'Neil et al., 1969). It is expressed in the same form as that derived by Epstein et al. (1953).

Many different versions of the paleotemperature equation have been used in the literature (Craig, 1965; Epstein et al., 1953; O'Neil et al., 1969; Shackleton, 1974; and others). The differences, however, are minor and the calculated temperatures using any of the equations differ only slightly.

Shackleton's (1974) equation is used here because it is more accurate at the low temperatures found on the 
ocean floor and because data from the present study will be compared with that derived by Shackleton and Kennett (1975) from the Campbell Plateau in the Southern Ocean (Site 277). Site 277 and Sites 511 and 512 of this report are the only Paleogene southern high-latitude sites for which paleotemperatures have been derived. The actual paleotemperatures derived by this means for the Leg 71 material are indicated by the scales on Figures 3 and 4 . It should be emphasized that these paleotemperatures are by no means absolute in view of the various assumptions which must be made in deriving the equation just discussed. In assessing the significance of the paleotemperature values, it is useful to review further the assumptions and limitations surrounding their derivation.

The isotopic temperature is a function of the difference between the ${ }^{18} \mathrm{O} /{ }^{16} \mathrm{O}$ ratio of the carbonate and the ${ }^{18} \mathrm{O} /{ }^{16} \mathrm{O}$ ratio of the water in which it was precipitated. With fossil material, the water in which the carbonate was precipitated is not available; thus the ${ }^{18} \mathrm{O} /{ }^{16} \mathrm{O}$ ratio must be estimated. The two main factors affecting the ${ }^{18} \mathrm{O} /{ }^{16} \mathrm{O}$ ratio of seawater at any location are (1) continental ice volume and (2) local evaporation, precipitation, and fresh-water influx (Craig and Gordon, 1965). Regional and local isotopic variations are difficult to infer for the past because conditions of circulation, variations in precipitation/evaporation, temperature, and geography were different. For this reason some workers, such as Savin et al. (1975), used the present isotopic variation as a guide for past water isotopic compositions. Shackleton and Kennett (1975) did not make any local or regional corrections for past isotopic water compositions because any estimate made would be unreliable. To minimize the effect of local variations, open ocean materials must be used. Sediments of the Falkland Plateau have been characteristic of open ocean conditions since the Late Cretaceous (Barker, Dalziel, et al., 1977).

Today, the overall average isotopic composition of the open ocean is approximately $-0.28 \%$ relative to PDB (Craig, 1965). Prior to the accumulation of the Antarctic ice sheet, this value must have been isotopically more negative, because the ice now stored on the ice caps is isotopically light. To estimate the isotopic composition of the preglacial ocean, it is necessary to put all of the water now locked up in polar ice back into the oceans. Craig (1965) estimated a preglacial ocean $0.5 \%$ lighter than the present-day ocean. Using models representing profiles of the Antarctic ice sheet, Shackleton and Kennett (1975) utilized the work of Gonfiantini et al. (1963), Picciotto et al. (1967), Nye (1959), and Epstein et al. (1965) to arrive at its bulk average isotopic composition. Assuming that all of this light ice ( $-50 \%$ ) were put back into the oceans, ocean waters would become lighter by $0.9 \%$. This would lower the average isotopic composition of today's oceans from $-0.28 \%$ to approximately $-1.2 \%$ relative to PDB. The value $-1.2 \%$ should be used as $\delta_{w}$ in the paleotemperature equation for all samples older than middle Miocene, because it was during the middle Miocene that a substan- tial Antarctic ice cap developed (Shackleton and Kennett, 1975; Savin et al., 1975; Kennett et al., 1974).

In the present study, surface temperatures were derived from planktonic foraminifers. Since most planktonic foraminifers live within 400 meters of the ocean surface, different species that live at different depths record different isotopic temperatures (e.g., Emiliani, 1954, 1971; Douglas and Savin, 1973, 1978). There are no species of planktonic foraminifers living today that existed during the Paleogene. Thus, for Paleogene material, it is not known whether the planktonic foraminifers were truly surface dwelling. However, Savin et al. (1975) have determined that the depth ranking of Holocene genera is the same as the depth ranking of extinct species of the same genera or morphology as far back as the Cretaceous. Douglas and Savin (1973) concluded that the uncertainty in depth habitat of Tertiary planktonic foraminifers does not significantly bias any surface paleotemperature calculations. Savin et al. (1975) cautioned, however, that the growth temperatures calculated from the isotopic compositions of planktonic foraminifers must always be interpreted as minimum values for surface temperatures.

Bottom water temperatures in the present study were derived from the oxygen isotopic compositions of benthic foraminifers. There is much evidence, however (Duplessy et al., 1970; Shackleton, 1974; Shackleton and Kennett, 1975; Woodruff et al., 1980; Savin et al., 1975) that many species of benthic foraminifers do not secrete their tests in isotopic equilibrium with the surrounding water. Smith and Emiliani (1968) suggested that in mixed benthic assemblages, nonequilibrium effects tend to be cancelled out or to be held at a constant value when relatively large samples are analyzed. They further suggested that nonequilibrium effects are held constant only if there is internal consistency in the genera analyzed in a mixed benthic assemblage. To this end, genera commonly picked at Site 511 were Nodosarella, Pullenia, Gyrodina, Pyrgo, Nonion, Cibicides, Bulimina, Eponides, Stilostomella, Nodosaria, Cassidulina, and Anomalina. Most of these genera were used in Shackleton and Kennett's (1975) study. At Site 512 monospecific benthic samples were used.

\section{DISCUSSION}

The Antarctic continent has not always been covered with ice. Evidence from paleomagnetic studies shows that it has been in a polar position since the Late Cretaceous (McElhinny, 1973), yet evidence from a wide variety of geologic records indicates that the continental glaciation of Antarctica was not initiated until sometime in the middle Cenozoic (Shackleton and Kennett, 1975; Savin et al., 1975). There is a considerable debate over the timing of Antarctic glaciation, although most workers agree on the existence of an extensive Antarctic ice cap at least by $14 \mathrm{Ma}$ (Kerr, 1982).

Almost all of the evidence concerning Cenozoic Antarctic glaciation has been derived from deep sea sediment studies in the high-latitude Southern Ocean. Paleoceanographic events in the Southern Ocean and cir- 
cum-Antarctic region are intimately tied to the history of Antarctic continential glaciation (Kennett, 1977). As was stated in the introduction, the present study was undertaken to provide the oxygen and carbon isotope record for the Paleogene in the high-latitude South Atlantic, and to tie this record to the paleoceanographic and geologic evolution of the Southern Ocean region.

The Eocene and Oligocene sediments cored at Sites 511 and 512 allow us to record events which lie within a very critical time frame for worldwide oceanic development, climatic change, and paleobiogeographic evolution and distribution. The Eocene/Oligocene boundary at Site 511 is an especially important reference datum for the present study, and it is fortunate that this boundary has been determined with a reasonable degree of certainty. It is placed at the top of Section 511-17-1 by Krasheninnikov and Basov (this volume) on the basis of the last occurrence of Globigerapsis index, and by Wise (this volume) on the basis of the last occurrence of the Discoaster saipanensis. These assigned levels agree well with the placement based on palynomorphs (Goodman and Ford, this volume).

\section{Correlation of Isotope and Paleoecologic Data}

Detailed paleontologic data from Leg 71 studies can be tied intimately to the oxygen isotope paleotemperature data for Sites 511 and 512. Most significant is a paleoclimatic analysis based on changes in radiolarian assemblages (Weaver, this volume) that correlates quite well with the oxygen isotope paleotemperature trends established for the Eocene and early Oligocene.

Beginning in the middle Eocene (Site 512), calculated paleotemperatures derived from oxygen isotopes of both planktonic and benthic foraminifers fluctuated in a rather narrow temperature range between $8^{\circ} \mathrm{C}$ and $11^{\circ} \mathrm{C}$ (Fig. 3). There was no appreciable difference between bottom and surface water temperatures, hence no evidence of a thermocline. For the late Eocene and earliest Oligocene, as represented by Sections 511-20-2 to 511$12-2$, isotopic paleotemperatures from both planktonic and benthic foraminifers indicate relatively warm temperatures similar to those in the middle Eocene of Site 512 (Fig. 4). Between Sections 511-20-2 and 511-18-1, late Eocene surface water isotopic temperatures at Site 511 rose approximately $2^{\circ} \mathrm{C}$ and bottom water isotopic temperatures rose approximately $5^{\circ} \mathrm{C}$. From Sections 511-18-1 through 511-17-1, latest Eocene surface and bottom water isotopic temperatures dropped from about $12.5^{\circ} \mathrm{C}$ to $8^{\circ} \mathrm{C}$ (Fig. 4). According to Weaver (this volume), radiolarian assemblages from this late Eocene and earliest Oligocene interval (including Core 511-16) indicate relatively warm conditions and cool temperate waters.

By Section 511-15-1, early Oligocene isotopic bottom water temperatures had risen $3^{\circ} \mathrm{C}$ to about $11^{\circ} \mathrm{C}$. Between Sections 511-15-1 and 511-12-2, early Oligocene surface water isotopic temperatures remained at about $11^{\circ} \mathrm{C}$, but bottom water temperatures at the site dropped sharply from $11^{\circ} \mathrm{C}$ to $3^{\circ} \mathrm{C}$, an $8^{\circ} \mathrm{C}$ temperature drop (Fig. 4). By Section 511-12-1, surface water temperatures dropped to $6^{\circ} \mathrm{C}$, representing a $5^{\circ} \mathrm{C}$ difference.
In close agreement with these isotope results, the overall radiolarian assemblage changed with respect to dominant species between Cores 511-15 and 511-12 (Weaver, this volume). Warm-water radiolarians, such as Calocycletta, disappear and cooler water genera begin to dominate and persist through Core 11 . Weaver considers this interval transitional, suggesting upwelling conditions during a progressive climatic deterioration in the earliest Oligocene (Weaver, this volume). He further suggests that at this time the convergence between cool temperate and subantarctic waters lay over the site. Eventually, the subantarctic waters transgressed over Site 511, but the exact timing of this event could not be ascertained from the radiolarian data.

In agreement with Weaver's radiolarian data, Bratseva (this volume) notes a similar sharp assemblage change between Cores 511-12 and 511-15. In her example, the change is in the composition of the dinoflagellate floras, but presumably the change she describes also reflects temperature or climatic change. For the early Oligocene, represented in Sections 511-12-1 through 511-3-3, isotopic paleotemperature curves are characterized by the significant difference between surface and bottom water temperatures. Prior to this, surface and bottom water temperatures at any given time did not differ significantly. The drastic drop in bottom water temperatures probably reflects the initial development of the presentday system of bottom waters known as the psychrosphere (Kennett and Shackleton, 1976). Through this interval surface water isotopic temperatures at Site 511 averaged $7^{\circ} \mathrm{C}$ and bottom water isotopic temperatures averaged $3^{\circ} \mathrm{C}$. However, parallel shifts in both the surface and bottom water temperatures, by as much as $4^{\circ} \mathrm{C}$, occurred during this time.

Between Cores 511-9 and 511-2, the radiolarian assemblage became indicative of antarctic rather than subantarctic conditions at Site 511 and of further climatic deterioration (Weaver, this volume). Weaver believes that radiolarians in these cores represent the northerly elements of a broad antarctic-subantarctic biogeographic province encompassing over $18^{\circ}$ of latitude in the circum-Antarctic during the early Oligocene.

Weaver notes a slight amelioration of climate by Core 511-5, as represented by the reappearance of two warmwater genera. He suggests this warming possibly represents a southerly shift of a warmer subantarctic water mass over the site. The oxygen isotope data also show a warming in Core 5, particularly in the benthic record. This event is short-lived, because by Section 511-5-3, benthic temperatures are back down to about $2^{\circ} \mathrm{C}$ while surface water temperatures are about $7^{\circ} \mathrm{C}$.

Between Sections 511-3-3 and 511-3-1, isotopic temperatures increased significantly. Surface water isotopic temperatures at Site 511 rose to about $11^{\circ} \mathrm{C}$ by Section 511-3-1 and bottom temperatures approximated $6.5^{\circ} \mathrm{C}$.

Information from the foraminiferal assemblage at Sites 511 and 512 can also be correlated with the radiolarian and isotopic data for these sites. Basov and Krasheninnikov (this volume) note a change in benthic species diversity from $10-15$ species per sample during the middle Eocene to 5-10 species per sample during the late 
Eocene and early Oligocene. They believe that much of this change is related to a temperature drop in the bottom waters at Sites 511 and 512, in agreement with the isotopic data. Krasheninnikov and Basov (this volume) also note a change in the planktonic species diversity from the middle Eocene to the early Oligocene. Planktonic foraminifers of the middle Eocene are relatively diverse. A decrease in diversity is observed in the late Eocene, along with the disappearance of warm-water species. The species diversity in the early Oligocene is the same as in the late Eocene. However, warm-water genera such as Globigerapsis and Acarinina have disappeared and have been replaced by more cosmopolitan foraminifers.

By the latest Eocene, indications of climatic change were reflected in the oxygen isotopic composition of the Southern Ocean at Site 511. There were two cooling events surrounding the Eocene/Oligocene boundary. Below the boundary, surface and bottom water temperatures dropped by equal amounts to about $8^{\circ} \mathrm{C}$. At this time, no thermocline was present. Temperatures rose for a short period to about $11^{\circ} \mathrm{C}$ in the earliest Oligocene and there was still no thermocline. Shortly afterwards, still in the early Oligocene, a dramatic and abrupt drop in surface and bottom water temperatures occurred. Bottom water temperatures, at $2^{\circ} \mathrm{C}$, were significantly colder than surface water temperatures, at $7^{\circ} \mathrm{C}$. The formation of a thermocline at this time and the influx of cold intermediate-level (and presumably abyssal) waters changed the general character of the world's oceans as circulation patterns and water masses assumed present-day characteristics.

\section{Comparison of High-Latitude South Atlantic and South Pacific Isotope Records}

To date, the only detailed paleotemperature curves for the Tertiary in the high-latitude Southern Ocean exist from Site 277. They document an isotopic paleotemperature drop of $4-5^{\circ} \mathrm{C}$ in surface and bottom waters during the earliest Oligocene (Shackleton and Kennett, 1975). Surface and bottom water isotopic temperatures for the middle Eocene were about $13^{\circ} \mathrm{C}$, whereas for the late Eocene, surface and bottom water isotopic temperatures decreased to $11^{\circ} \mathrm{C}$ and $8^{\circ} \mathrm{C}$ respectively.

Keigwin (1980) resampled the Eocene/Oligocene boundary section at Site 277 using a much closer sampling interval and also documented a $4^{\circ} \mathrm{C}$ cooling within the entire water column at this site. Keigwin (1980) believed, however, that the abrupt temperature decrease occurred at the Eocene/Oligocene boundary at Site 277 and not within the earliest Oligocene as suggested by Shackleton and Kennett (1975).

If the isotopic trends documented in the present study reflect the same paleoceanographic conditions operative on the Campbell Plateau, then the Atlantic-sector data support the interpretation of Shackleton and Kennett (1975), i.e., the abrupt cooling event and divergence of surface water and bottom temperature values occurred within the early Oligocene rather than across the Eocene/ Oligocene boundary as suggested by Keigwin (1980). The evidence for an early Oligocene change in Site 511 could have been stronger, however, if core recovery had been higher in the greatly expanded lower Oligocene section.

The abrupt and dramatic temperature decrease at or near the Eocene/Oligocene boundary noted by many researchers (Table 1) leads us to ask whether these recorded oxygen isotope events occurred concurrently worldwide, or whether they did in fact occur at significantly different times in different places. Perhaps the best regional agreement is among the Southern Ocean sites, where the event seems to have occurred within the early Oligocene. Worldwide, however, the data among the various studies are sufficiently sparse that no clear picture can be discerned at present, and resolution of the question of synchrony, diachrony, or time-transgression of the event(s) must await the acquisition of more and better Eocene-Oligocene sections.

\section{Significance of the Eocene-Oligocene Cooling Event}

Regardless of the exact timing of this event, the oceans of the world abruptly cooled within the late Eocene-earliest Oligocene interval, as indicated by a large $\delta^{18} \mathrm{O}$ increase. Shackleton and Kennett (1975) have interpreted this dramatic cooling as a critical stage or threshold in the development of Antarctic glaciation.

Although no continental ice sheet had yet formed, Shackleton and Kennett (1975) argued that the planktonic isotopic paleotemperature drop implies sea-level glaciation and that benthic paleotemperatures indicated the onset of deep-water circulation dominated by the formation of cold bottom waters around the Antarctic continent. In effect, they document the inception of thermohaline circulation similar to present-day circulation.

It is debatable what triggered this event, although paleoceanographic change must be principally related to continental and plate movement. In the Paleocene, Antarctica and Australia were joined at the polar position (Kennett, 1977). Australia began to drift north during the Eocene, establishing an ocean between the two continents that was blocked to the east by the South Tasman Rise and Tasmania. The Drake Passage was also blocked by a land bridge connecting South America to Antarctica (Shipboard Scientific Party et al., 1977). The only known interocean circulation at this time linked the tropical Atlantic and Pacific oceans. There have been suggestions of the existence of a seaway between the Ross and Weddell seas through which a proto-circumpolar current may have flowed (the "Shackleton Seaway" of Zinsmeister, 1978). Direct evidence for such a seaway is lacking, however, and most current scenarios do not discuss this possibility. Nevertheless, clockwise subpolar gyres in the South Atlantic and Pacific oceans are postulated to have existed in the absence of circumpolar circulation (Haq, 1981). In the late Eocene, the subsidence of the South Tasman Rise allowed at least surface water communication between the Indian and Pacific oceans (Kennett et al., 1974). Although the Drake Passage was still closed, the subsidence of the Rise enhanced the development of circumpolar circulation sufficiently to cool subantarctic and antarctic sur- 
face and bottom waters. This coincides with the steady destruction of equatorial circulation and the decoupling of warm-water subtropical gyres from colder subantarctic gyres (Kennett, 1978).

Shackleton and Kennett (1975) suggested further that the abrupt temperature drop near the Eocene/Oligocene boundary represented the formation of ice at sea level around the Antarctic continent and the initiation of bottom waters close to freezing. Although an abrupt temperature decrease at this time can be documented in deep sea sediments worldwide (Table 1), whether this temperature drop is truly representative of sea ice formation has been a topic of sharp debate. Small amounts of ice-rafted debris in Eocene and Oligocene cores off West Antarctica have been cited as evidence for limited sea-level glaciation for these times (Margolis and Kennett, 1971). Le Masurier (1972) has postulated volcanogenic evidence for extensive glaciation during the Paleogene of West Antarctica. However, the absence of icerafted debris in the Eocene and lower Oligocene material of Legs $28,29,36$, and 71 seems to indicate that appreciable ice did not exist on the Antarctic continent at this time. Alternatively, these sites may have been north of the iceberg limit when sea-level glaciers and sea ice were presumably forming around Antarctica. The first unequivocal identification of ice-rafted material in the Antarctic marine sequence is from the Ross Sea and is late Oligocene in age (Hayes and Frakes, 1975).

The formation of cold bottom waters and deteriorating climate increased deep water circulation activity, as is evidenced by the widespread erosion of bottom sediments and the numerous hiatuses centered upon the Eocene/ Oligocene boundary (Moore et al., 1978). At Site 511, most of the Oligocene and the Miocene are missing. At Site 512, the upper Eocene, Oligocene, and lower Miocene are absent in the sedimentary record.

Increased cold water production led to the development of the psychrosphere at this time, as is noted by the divergence in the isotopic temperatures recorded between planktonic and benthic foraminifers at Sites 511 and 292.

Regardless of whether Shackleton and Kennett's (1975) early Oligocene buildup of sea level ice has validity, the oxygen isotope data do indicate a rapid drop in surface and bottom water temperatures to a level that may or may not have been cold enough to initiate ice formation around Antarctica. The problem here is one of absolute temperatures versus isotopic temperatures. Although some workers (Mercer, 1978; Savin, 1977) may reject Shackleton and Kennett's isotopic paleotemperatures as being too high for the formation of sea ice, it must be remembered that these are not absolute temperatures. The Oligocene isotopic temperatures $\left(2^{\circ} \mathrm{C}\right.$ to $5^{\circ} \mathrm{C}$ ) recorded from the benthic foraminifers from most studies are compatible with present-day bottom water temperatures at these sites. In fact, the surface and bottom water isotopic paleotemperatures from the Site 511 Oligocene section are in agreement with recorded temperatures at the surface and ocean bottom recorded today at Site 511 (Gordon, 1971; NODC, 1974).
If we assume that the present is one key to the past, and we know that there is a substantial amount of sea ice around Antarctica today producing surface and bottom waters with present-day temperatures about the same as our isotopic paleotemperatures over the same site, we can then infer that the same mechanism which creates the present-day water masses in the Antarctic and sub-Antarctic could have existed in the Oligocene. Since the Eocene/Oligocene boundary temperature event, the CCD has remained depressed in the world's oceans, and cold bottom water activity is as vigorous today as it was when it was initiated.

\section{CARBON ISOTOPES}

There are many factors which might affect the carbon isotope ratios in planktonic and benthic foraminifers. The $\delta^{13} \mathrm{C}$ of foraminiferal tests may reflect the $\delta^{13} \mathrm{C}$ of the dissolved bicarbonate ion in the seawater in which the tests grew. Broecker (1971) relates changes in the carbon isotope ratio of foraminifers to changes in ocean chemistry, particularly in oceanic phosphate content. Goodney et al. (1980) suggest that changes in primary productivity, local variations in upwelling, and speciesdependent vital effects may possibly affect the carbon isotope ratio in foraminifers. Shackleton (1977) suggests that a reduction in continental biomass during glaciations might lower carbon isotope ratios.

Douglas and Savin (1978), comparing the carbon isotope ratios of adult and juvenile forms in Tertiary foraminifers, found that the ratios are as much as $2 \%$ more negative in juveniles. When carbon isotope data of planktonic adults are considered, Douglas and Savin note a negative correlation between oxygen isotope ratios and carbon isotope ratios. As $\delta^{18} \mathrm{O}$ becomes more positive, $\delta^{13} \mathrm{C}$ becomes more negative. This is not the case at Site 511.

Kroopnick (1974) points out that modern ocean deep waters formed in the North Atlantic have a relatively positive $\delta^{13} \mathrm{C}$ composition initially, because of biological utilization of light carbon in the surface water. Through time, the dissolved carbon becomes lighter as this deep water mass moves south and organic carbon is oxidized and returned as dissolved carbon.

The carbon isotope curves for planktonic and benthic foraminifers from the middle Eocene section of Site 512 appear to be an approximate mirror image of one another (Fig. 3). The benthic foraminifers consistently record lighter carbon isotope ratios, when compared to the planktonic curve, by an average of approximately $0.7 \%$, and also record lighter carbon isotope ratios as oxygen isotopes become lighter (as temperatures increase). The planktonic foraminifers consistently record heavier carbon isotope ratios as temperatures decrease and oxygen isotope ratios become heavier.

The carbon isotope curves at Site 511 for planktonic and benthic foraminifers show a relatively large difference between the carbon isotope ratios (on the order of $2.0 \%$ ) and are characterized by large fluctuations between samples (Fig. 4). The planktonic and benthic foraminifer curves appear to be roughly parallel. As the ox- 
ygen isotope ratios in both planktonic and benthic foraminifers become lighter, so do the carbon isotope ratios.

The significant difference in the benthic carbon isotope ratios between the middle Eocene and early Oligocene might indicate productivity changes associated with upwelling. If the oxygen isotope changes in the early Oligocene represent the formation of near freezing surface water around Antarctica, then it might be expected that because of increased circulation and upwelling benthic foraminiferal carbon values would be lighter after the early Oligocene temperature event. Benthic carbon isotope values are lighter by up to $2.0 \%$ in the late Eocene and early Oligocene sections at Site 511. Part of this difference may be due to the use of mixed benthic genera from Site 511 and monospecific samples from Site 512 for isotope analysis.

At present, there seems to be no explanation why the carbon isotope planktonic and benthic foraminifer curves at Site 512 during the middle Eocene have a negative correlation, whereas the curves at Site 511 for the late Eocene and early Oligocene are parallel. Comparison of middle Eocene benthic carbon isotope variations at Site 512 with those at Site 277 (Shackleton and Kennett, 1975) indicates a general similarity of values between the two curves. It appears that throughout the middle Eocene foraminiferal carbon isotope ratios in the Southern Ocean became lighter by about $0.2 \%$. As at Site 512, Site 277 carbon isotope values of planktonic and benthic foraminifers exhibit a negative correlation.

The carbon isotope ratios of upper Eocene-lower Oligocene benthic foraminifers at Site 511 are about $1.8 \%$ lighter than the ratios recorded by Shackleton and Kennett (1975) at Site 277 for the same interval. Average planktonic foraminifer carbon isotope values at Site 511 are generally lighter by about $0.8 \%$ than the late Eocene-early Oligocene values reported by Shackleton and Kennett (1975). The carbon isotope differences between Sites 511 and 277 may be due to the observed differences in the isotopic composition between dissolved carbon in Pacific and Atlantic deep waters, amounting to $1.0 \%$ (Shackleton and Kennett, 1975). Middle Eocene planktonic carbon isotope values at Site 512 are, on the average, about $1 \%$ lighter than Site 277 middle Eocene carbon isotope values.

\section{SUMMARY AND CONCLUSIONS}

The oxygen and carbon isotope record based on the analysis of planktonic and benthic foraminifers for portions of the middle Eocene, late Eocene, and early Oligocene has provided a detailed paleoclimatic history at DSDP Sites 511 and 512.

Surface water temperature for the middle Eocene at Site 512 fluctuated $\pm 2^{\circ} \mathrm{C}$ but generally averaged $9^{\circ} \mathrm{C}$. Bottom water temperatures over Site 512 were generally a degree lower than surface water temperatures. Surface and bottom water temperatures recorded at Site 512 are generally $2^{\circ} \mathrm{C}$ colder than those from other studies (Shackleton and Kennett, 1975; Savin et al., 1975; Douglas and Savin, 1971, 1973, 1975) in other regions of the world. The temperatures indicate relatively cool temperate waters.
Surface water temperature at Site 511 initially averaged $11^{\circ} \mathrm{C}$ in the late Eocene, but dropped in a zigzag manner to an average of $7^{\circ} \mathrm{C}$ into the earliest Oligocene. Bottom water temperatures over Site 511 paralleled the surface water temperature trend during the late Eocene and earliest portion of the Oligocene. Bottom temperatures at Site 511 closely approximate those in Shackleton and Kennett's (1975) study of DSDP Site 277. At some point in the early Oligocene, between Sections 511-15-1 and 511-12-1, bottom water temperatures suddenly and dramatically dropped to an average of $2^{\circ} \mathrm{C}$ over Site 511. In addition, this temperature drop was accompanied by the formation of a $5^{\circ} \mathrm{C}$ temperature gradient between surface and bottom water over Site 511 during the early Oligocene; this heralded the beginning of the psychrosphere and the formation of an ocean dominated by thermohaline circulation. Shackleton and Kennett (1975) suggested that the dramatic temperature decrease near the Eocene/Oligocene boundary represented the initiation of sea level glaciation in Antarctica and the formation of sea ice which produced cold bottom waters reminiscent of those of today.

Beyond the Southern Ocean DSDP sites, bottom water temperature decreases have been found in benthic foraminifers by other workers examining Eocene/Oligocene boundary sections at DSDP Sites 44, 167, 171, 292, $357,398,119$, and 401 . An apparently equal concurrent temperature decrease occurred in the planktonic foraminifers at these sites, with the exception of Site 292. At no other site, however, was the temperature decrease accompanied by a sharp divergence between bottom and surface water temperatures of the magnitude recorded at Site 511.

The faunal assemblages from Site 511 provide further evidence of the deterioration of climate during the Eocene and Oligocene. Weaver (this volume) notes changes in the radiolarian assemblages which can be directly correlated to the changing temperature curve at Site 511 . Weaver suggested that the changes in the radiolarian assemblages indicate the movement of a subantarctic-antarctic water mass boundary over Site 511. Such an expansion in the antarctic water mass would explain well the sharp drop in and divergence of bottom and surface water temperatures at Site 511. Conversely, the fact that a comparable divergence is not generally seen at other DSDP sites and outcrop localities, particularly those towards the equator, can be explained by the absence in these regions of a migrating water mass boundary as sharp as that which separates subantarctic and antarctic waters. In other words, the sharp temperature drop and the divergence may be in part a peculiarity of the oceanographic regime of the Southern Ocean. One would not expect this situation to be duplicated precisely elsewhere, particularly in more northerly DSDP sites where ocean circulation patterns are quite different. In these areas a more gradual Eocene-Oligocene cooling trend might be expected. It would not, of course, be unreasonable to expect some type of early Oligocene temperature decrease at other DSDP sites, since the climatic event which caused the early Oligocene expansion of the antarctic water mass in the area of the Falkland Plateau should certainly have been felt to some extent elsewhere. 
The foraminiferal assemblages at Sites 511 and 512 can be correlated with the isotopic and radiolarian data at these sites. Basov and Krasheninnikov and Krasheninnikov and Basov (this volume) note decreasing foraminiferal species diversity between the middle Eocene and late Eocene, and between the late Eocene and Oligocene. They believe that these changes are related to a general cooling of surface and bottom waters at Sites 511 and 512. The conditions which led to the climatic deterioration through the Eocene and Oligocene and the abrupt decrease in surface and bottom water temperatures are still a subject of much debate.

The factors affecting the carbon isotope composition of foraminiferal calcite are complex and not well understood. Furthermore, very little is known about what affects the carbon isotope composition of the oceans at any locale. Yet some trends are evident in the Leg 71 data. Relatively light $\delta^{13} \mathrm{C}$ values in the late Eocene and early Oligocene benthic foraminifers at Site $511 \mathrm{might}$ reflect increased productivity associated with upwelling that results from increased cold water production and more vigorous oceanic circulation.

\section{ACKNOWLEDGMENTS}

This article was condensed from a Master's thesis submitted by the senior author to the Department of Geology, Florida State University, in partial fulfillment of degree requirements. We thank Kimberly Williams for typing the manuscript, Mary Parker for editing, and Dennis Cassidy and Kim Riddle for photographing the figures. We are grateful to George DeVore and David Whittington for helpful discussion and to Roger Bottner and Cindy Ryan (Amoco Production Co., New Orleans) for their generous assistance. The research was supported by grants OCE $80-85208$ and DPP $80-23696$ to D. F. Williams, in whose laboratory the isotope measurements were made, and by grant DPP 80-20382 to S. W. Wise, in whose laboratory the rest of the study was conducted.

\section{REFERENCES}

Barker, P. F., Dalziel, I. W. D., et al., 1977. Init. Repts. DSDP, 36: Washington (U.S. Govt. Printing Office).

Berger, W. H., and Winterer, E. L., 1974. Plate stratigraphy and the fluctuating carbonate line. Int. Ass. Sedimentol. Spec. Publ., 1: $11-48$.

Boersma, A., and Shackleton, N. J., 1977. Tertiary oxygen and carbon isotope stratigraphy, Site 357 (mid latitude South Atlantic. In Supko, P. R., Perch-Nielsen, K., et al., Init. Repts. DSDP, 39: Washington (U.S. Govt. Printing Office), 911-924.

Broecker, W. S., 1971. A kinetic model for the chemical composition of seawater. Quat. Res., 1:188-207.

Corliss, B. H., 1981. Deep Sea benthonic foraminiferal faunal turnover near the Eocene/Oligocene boundary. Mar. Micropaleontol., $6: 367-384$.

Craig, H., 1965. The measurement of oxygen isotope paleotemperatures. Stable Isotopes in Oceanographic Studies and Paleotemperatures: Pisa (Consiglio Nazionale delle Ricerche), pp. 161-182.

Craig, H., and Gordon, L. I., 1965. Deuterium and oxygen-18 variations in the ocean and the marine atmosphere. Stable Isotopes in Oceanographic Studies and Paleotemperatures: Pisa (Consiglio Nazionale delle Ricerche), pp. 9-129.

Devereux, I., 1967. Oxygen isotope paleotemperature measurements on New Zealand Tertiary fossils. N. Z. J. Sci., 10:988.

Dixon, W. S., and Massey, F. S., 1957. Introduction to Statistical Analysis: New York (McGraw-Hill).

Douglas, R. G., and Savin, S. M., 1971. Isotopic analysis of planktonic Foraminifera from the Cenozoic of the Northwest Pacific, Leg 6. In Fischer, A. G., Heezen, B. C., et al., Init. Repts. DSDP, 6: Washington (U.S. Govt. Printing Office), 1123-1127. 1973. Oxygen and carbon isotope analysis of Cretaceous and Tertiary foraminifera from the central north Pacific. In
Winterer, E. L., Ewing, J. I., et al., Init. Repts. DSDP, 17: Washington (U.S. Govt. Printing Office), 591-606.

1975. Oxygen and carbon isotope analyses of Tertiary and Cretaceous microfossils from Shatsky Rise and other sites in the North Pacific Ocean. In Larson, R. L., Moberly, R., et al., Init. Repts. DSDP, 32: Washington (U.S. Govt. Printing Office), 509-520.

1978. Oxygen isotopic evidence for the depth stratification of Tertiary and Cretaceous planktonic foraminifera. Mar. Micropaleontol. 3:175-196.

Duplessy, J. C., Lalou, C., and Vinot, A. C., 1970. Differential isotopic fractionation in benthic foraminifera and paleotemperatures reassessed. Science, 168:250-251.

Emiliani, C., 1954. Depth habitats of some species of pelagic foraminifera as indicated by oxygen isotope ratios. Am. J. Sci., 252: 149-158.

1955. Pleistocene temperatures. J. Geol., 63:538-578.

1971. Depth habitats and growth stages of pelagic foraminifera. Science, 173:1122-1124.

Epstein, S., Buchsbaum, R., Lowenstam, H. A., and Urey, H. C., 1953. Revised carbonate-water isotopic temperature scale. Geol. Soc. Am. Bull., 64:1315-1326.

Epstein, S., Sharp, R. P., and Gow, A., 1965. Six-year record of oxygen and hydrogen isotope variations in South Pole firn: J. Geophys. Res., 70:1809-1814.

Gonfiantini, R., Togliatti, V., Tongiorgi, E., DeBreuk, W., and Picciotto, E., 1963. Snow stratigraphy and oxygen isotope variations in the glaciological pit at King Baudouin Station, Queen Maud Land, Antarctica. J. Geophys. Res., 68:3791-3798.

Goodney, D. E., Margolis, S. V., Dudley, W. C., Kroopnick, P., and Williams, D. F., 1980. Oxygen and carbon isotopes of recent calcareous nannofossils as paleoceanographic indicators. Mar. Micropaleontol., 5:31-42.

Gordon, A. L., 1971. Oceanography of Antarctic waters. Antarctic Oceanology, J. Antarct. Res. Sur. (ANTSA4), 15:169-203.

Haq, B. U., 1981. Paleogene paleoceanography: Early Cenozoic oceans revisited. Oceanol. Acta, 71-82.

Hayes, D. E., and Frakes, L. A., 1975. General synthesis, Deep Sea Drilling Project Leg 28. In Hayes, D. E., Frakes, L. A., et al., Init. Repts. DSDP, 28: Washington (U.S. Govt. Printing Office), 919-942.

Keigwin, L. D. Jr., 1980. Oxygen and carbon isotope analyses from Eocene/Oligocene boundary at DSDP Site 277. Nature, 287: $722-725$.

Kennett, J. P., 1977. Cenozoic evolution of Antarctic glaciation, the Circum-Antarctic Ocean, and their impact on global paleoceanography. J. Geophys. Res., 82(27):3843-3860.

1978. The development of planktonic biogeography in the Southern Ocean during the Cenozoic. Mar. Micropaleontol., 3: 310-346.

Kennett, J. P., Houtz, R. E., Andrews, J. E., Edwards, A. R., Gostin, V. A., et al., 1974. Development of the Circum-Antarctic Current. Science, 186:144-147.

Kennett, J. P., Houtz, R. E., et al., 1975. Init. Repts. DSDP, 29: Washington (U.S. Govt. Printing Office).

Kennett, J. P., and Shackleton, N. J., 1976. Oxygen isotopic evidence for the development of the psychrosphere $38 \mathrm{~m}$. yr. ago. Nature, 260:513-515.

Kerr, R. A., 1982. New evidence fuels Antarctic ice debate. Science, 216:973-974.

Kroopnick, P., 1974. The dissolved $\mathrm{O}_{2}-\mathrm{CO}_{2}-{ }^{13} \mathrm{C}$ system in the eastern equatorial Pacific. Deep-Sea Res., 21:211-227.

Le Masurier, W. E., 1972. Volcanic record of Cenozoic glacial history of Marie Byrd Land. In Adie, R. J., (Ed.), Antarctic Geology and Geophysics: Oslo (Universitetsforlaget), pp. 251-260.

McElhinny, M. W., 1973. Palaeomagnetism and Plate Tectonics: New York (Cambridge University Press).

Margolis, S. V., and Kennett, J. P., 1971. Cenozoic paleoglacial history of Antarctica recorded in sub-Antarctic deep-sea cores. Am. J. Sci., 271:1-36.

Mercer, J. H., 1978. Glacial development and temperature trends in the Antarctic and in South America. In Van Zinderen, and Bakker, E. M., (Eds.), Antarctic Glacial History and World Paleoenvironment: Rotterdam (Balkema), pp. 73-94. 
Miller, K. G., and Curry, W. B., in press. Eocene to Oligocene isotopic record in the Bay of Biscay. Nature.

Moore, T. C., Jr., van Andel, T. H., Sancetta, C., and Pisias, N., 1978. Cenozoic hiatuses in the pelagic sediments. Micropaleontology, 24:113-138.

National Oceanographic Data Center, 1974. Key to Oceanographic Records Documentation No. 1. User's Guide to NODC's Data Services: Washington (NODC).

Nye, J. F., 1959. The motion of ice sheets and glaciers. J. Glaciology, 3:493-507.

O'Neil, J. R., Clayton, R. N., and Mayeda, T. K., 1969. Oxygen isotope fractionation in divalent metal carbonates. J. Chem. Phys., 51:5547-5558.

Picciotto, E., Cameron, R., Crozaz, G., Deutsch, S., and Wilgain, S., 1967. Determination of the role of snow accumulation at the Pole of Inaccessibility, East Antarctica: a comparison of glaciological and isotopic methods. Internal Report, University of Brussels and Ohio State University.

Ramsay, A. T. S., 1977. Sedimentological clues to paleoceanography. In Ramsay, A. T. S. (Ed.), Oceanic Micropaleontology: New York (Academic Press), pp. 1371-1453.

Savin, S. M., 1977. The history of the Earth's surface temperature during the last 100 million years. Ann. Rev. Earth Planet. Sci., 5:319-355.

Savin, S. M., Douglas, R. G., and Stehli, F. G., 1975. Tertiary marine paleotemperatures. Geol. Soc. Am. Bull., 86:1499-1510.

Shackleton, N. J., 1974. Attainment of isotopic equilibrium between ocean water and the benthonic foraminifera genus Uvigerina: Isotopic changes in the ocean during the last glacial. Colloq. Int. C.N.R.S., 219:203-210.

1977. Carbon-13 in Uvigerina: Tropical rainforest history and the equatorial Pacific carbonate dissolution cycles. In Anderson, N. R., and Malahoff, A. (Eds.), The Fate of Fossil Fuel $\mathrm{CO}_{2}$ in the Oceans (Vol. 6): New York (Plenum), 401-427.

Shackleton, N. J., and Kennett, J. P., 1975. Paleotemperature history of the Cenozoic and the initiation of Antarctic glaciation: Oxygen and carbon isotope analyses in DSDP Sites 277, 279, and 281. In Kennett, J. P., Houtz, R. E., et al., Init. Repts. DSDP, 29: Washington (U.S. Govt. Printing Office), 743-755.

Shipboard Scientific Party, Sliter, W., and Harris, W. V., 1977. Evolution of the southwestern Atlantic Ocean basin: Results of Leg 36, Deep Sea Drilling Project. In Barker, P. F., Dalziel, I. W. D., et al., Init. Repts. DSDP, 36: Washington (U.S. Govt. Printing Office), 993-1014.

Smith, P. B., and Emiliani, C., 1968. Oxygen isotope analysis of recent tropical Pacific benthonic Foraminifera. Science, 160: 1335-1336.

Vergnaud Grazzini, C., 1979. Cenozoic paleotemperatures at Site 398, eastern North Atlantic: Diagenetic effects on carbon and oxygen isotopic signal. In Sibuet, J. C., Ryan, W. B. E., et al., Init. Repts. $D S D P$, 47, Pt. 2: Washington (U.S. Govt. Printing Office), $507-512$.

Vergnaud Grazzini C., Pierre C., and Létolle R., 1978. Paloenvironment of the Northeast Atlantic during the Cenozoic: Oxygen and carbon isotope analyses at DSDP Sites 398,400 , and 401. Oceanol. Acta, 1(3):381-390.

Wise, S. W., Jr., 1981. Deep Sea drilling in the Antarctic: Focus on late Miocene glaciation and application of smear-slide biostratigraphy. In Warme, J. E., Douglas, R. G., and Winterer, E. L., (Eds.), The Deep Sea Drilling Project: A Decade of Progress. Soc. Econ. Paleontol. Mineral., Spec. Publ., 32:471-487.

Woodruff, F., Savin, S. M., and Douglas, R. G., 1980. Biological fractionation of oxygen and carbon isotopes by recent benthic foraminifera. Mar. Micropaleontol., 5:3-11.

Zinsmeister, W. J., 1978. Effect of formation of the West Antarctic Ice Sheet on shallow water marine faunas of Chile. Antarct. $J$. U.S., 13:25-26.
APPENDIX

Site 511 Benthic Foraminiferal Abundance

\begin{tabular}{|c|c|c|}
\hline Core/Section & Abundance ${ }^{\mathrm{a}}$ & Foraminifer \\
\hline \multirow[t]{4}{*}{$3-1$} & 2 & Pleurostomella \\
\hline & 1 & Pullenia \\
\hline & 1 & Cibicides \\
\hline & 3 & Nonion \\
\hline \multirow[t]{4}{*}{$3-2$} & 1 & Uvigerina \\
\hline & 3 & Pullenia \\
\hline & 4 & Nonion \\
\hline & 2 & Nodosaria longiscata \\
\hline \multirow{6}{*}{$3-3$} & 1 & Pleurostomella \\
\hline & 6 & Stilostomella \\
\hline & 2 & Pullenia \\
\hline & 1 & Cibicides \\
\hline & 1 & Eponides \\
\hline & 2 & Nonion \\
\hline \multirow[t]{4}{*}{$4-1$} & 1 & Lagena \\
\hline & 3 & Nodosarella subnodosa \\
\hline & 3 & Pullenia \\
\hline & 3 & Gyroidina \\
\hline \multirow[t]{6}{*}{$4-2$} & 1 & Anomalina \\
\hline & 1 & Pullenia \\
\hline & 2 & Eponides \\
\hline & 2 & Nodosaria longiscata \\
\hline & 2 & Stilostomella \\
\hline & 2 & Lagena \\
\hline \multirow[t]{8}{*}{$4-3$} & 1 & Pleurostomella \\
\hline & 1 & Bulimina \\
\hline & 2 & Pullenia \\
\hline & 1 & Lagena \\
\hline & 1 & Nodosarella subnodosa \\
\hline & 1 & Uvigerina \\
\hline & 2 & Anomalina \\
\hline & 1 & Eponides \\
\hline \multirow[t]{5}{*}{$5-1$} & 3 & Stilostomella \\
\hline & 1 & Pullenia \\
\hline & 1 & Pleurostomella \\
\hline & 1 & Nodosaria \\
\hline & 2 & Lagena \\
\hline \multirow[t]{4}{*}{$5-2$} & 1 & Nodosarella subnodosa \\
\hline & 1 & Pullenia \\
\hline & 1 & Gyroidina \\
\hline & 2 & Lagena \\
\hline \multirow[t]{5}{*}{$5-3$} & 3 & Stilostomella \\
\hline & 1 & Bulimina \\
\hline & 2 & Pullenia \\
\hline & $i$ & Nodosaria longiscata \\
\hline & 2 & Eponides \\
\hline \multirow[t]{5}{*}{$5-4$} & 2 & Nodosarella subnodosa \\
\hline & 2 & Anomalina \\
\hline & 2 & Stilostomella \\
\hline & 1 & Eponides \\
\hline & 1 & Gyroidina \\
\hline \multirow[t]{4}{*}{$6-2$} & 2 & Pullenia \\
\hline & 2 & Nodosaria longiscata \\
\hline & 1 & Pleurostomella \\
\hline & 2 & Bulimina \\
\hline \multirow[t]{6}{*}{$6-3$} & 1 & Gyroidina \\
\hline & 3 & Anomalina \\
\hline & 2 & Pullenia \\
\hline & 2 & Stilostomella \\
\hline & 1 & Nodosaria longiscata \\
\hline & 1 & Bulimina \\
\hline
\end{tabular}


J. P. MUZA, D. F. WILLIAMS, S. W. WISE, JR.

Appendix. (Continued).

\begin{tabular}{|c|c|c|}
\hline Core/Section & Abundance ${ }^{\mathrm{a}}$ & Foraminifer \\
\hline \multirow[t]{6}{*}{$6-4$} & 5 & Pullenia \\
\hline & 3 & Bulimina \\
\hline & 2 & Stilostomella \\
\hline & 2 & Lagena \\
\hline & 2 & Nodosarella subnodosa \\
\hline & 2 & Nodosaria longiscata \\
\hline \multirow[t]{7}{*}{$9-1$} & 3 & N. longiscata \\
\hline & 1 & Triloculina \\
\hline & 1 & Pullenia \\
\hline & 1 & Nodosarella subnodosa \\
\hline & 1 & Bulimina \\
\hline & 1 & Gyroidina \\
\hline & 1 & Cibicides \\
\hline \multirow[t]{7}{*}{$9-2$} & 3 & Stilostomella \\
\hline & 3 & Anomalina \\
\hline & 1 & Nodosaria longiscata \\
\hline & 1 & Triloculina \\
\hline & 1 & Pleurostomella \\
\hline & 1 & Pullenia \\
\hline & 1 & Cibicides \\
\hline \multirow[t]{7}{*}{$9-3$} & 2 & Triloculina \\
\hline & 2 & Anomalina \\
\hline & 2 & Pleurostomella \\
\hline & 1 & Gyroidina \\
\hline & 3 & Nonion \\
\hline & 1 & Pullenia \\
\hline & 1 & Eponides \\
\hline \multirow[t]{5}{*}{$9-4$} & 2 & Lagena \\
\hline & 1 & Anomalina \\
\hline & 1 & Pullenia \\
\hline & 2 & Eponides \\
\hline & 2 & Fissurina \\
\hline $9-5$ & 3 & Anomalina \\
\hline
\end{tabular}

Appendix. (Continued).

\begin{tabular}{|c|c|c|}
\hline Core/Section & Abundance $^{\mathrm{a}}$ & Foraminifer \\
\hline & 1 & Stilostomella \\
\hline & 1 & Nodosaria longiscata \\
\hline & 1 & Lagena \\
\hline & 2 & Bulimina \\
\hline \multirow[t]{5}{*}{$9-7$} & 2 & Eponides \\
\hline & 2 & Anomalina \\
\hline & 1 & Astacolus \\
\hline & 1 & Cassidulina \\
\hline & 1 & Pullenia \\
\hline \multirow[t]{5}{*}{$12-1$} & 5 & Pullenia \\
\hline & 2 & Gyroidina \\
\hline & 4 & Lagena \\
\hline & 3 & Stilostomella \\
\hline & 1 & Bulimina \\
\hline \multirow[t]{5}{*}{$12-2$} & 2 & Nodosaria longiscata \\
\hline & 1 & Nodosarella subnodosa \\
\hline & 2 & Anomalina \\
\hline & 1 & Gyroidina \\
\hline & 1 & Stilostomella \\
\hline \multirow[t]{2}{*}{$15-1$} & 2 & Eponides \\
\hline & 2 & Nodosaria longiscata \\
\hline \multirow[t]{3}{*}{$17-1$} & 1 & N. longiscata \\
\hline & 1 & Gyroidina \\
\hline & 2 & Eponides \\
\hline \multirow[t]{2}{*}{$17-3$} & 1 & Gyroidina \\
\hline & 1 & Stilostomella \\
\hline \multirow[t]{2}{*}{$18-1$} & 1 & Pleurostomella \\
\hline & 1 & Glandulina \\
\hline \multirow[t]{3}{*}{$20-2$} & 2 & Pullenia \\
\hline & 3 & Bulimina \\
\hline & 1 & Cibicides \\
\hline
\end{tabular}

a Specimens per analysis. 